\title{
SEA LEVEL IMPLICATIONS FROM LATE QUATERNARY/HOLOCENE PALEOSOLS FROM THE OUJIANG DELTA, CHINA
}

\author{
Daidu Fan ${ }^{1,2} \cdot$ Shuai Shang $^{1} \cdot$ George Burr ${ }^{3 *}$ \\ ${ }^{1}$ State Key Laboratory of Marine Geology, Tongji University, Shanghai 200092, China. \\ ${ }^{2}$ School of Geoscience, Yangtze University, Wuhan 430100, China. \\ ${ }^{3}$ Frontier Research Center for Future Earth, Department of Geosciences, National Taiwan University, Taipei 106, \\ Taiwan.
}

\begin{abstract}
We describe two coastal paleosols recovered in sediment cores from the Oujiang Delta, Southeast China. These provide useful benchmarks for past sea level change on the East China Sea coast. Radiocarbon $\left({ }^{14} \mathrm{C}\right)$ dates on charcoal and plant matter show that one formed during Marine Isotope Stage 3 (MIS 3) and was exposed for perhaps $20 \mathrm{ka}$, during the Last Glacial Maximum. The other formed in the Early Holocene and was briefly exposed, during a period of fluctuating sea level. Similar paleosols have been described from the Changjiang (Yangtze) Delta, and at many other sites from the East China Sea. The MIS 3 paleosol records a regional relative sea level of about $-27 \mathrm{~m}$ at the end of MIS 3. While this value is consistent with other paleo sea level estimates for the East China Sea region, it is much higher than predicted by eustatic sea level estimates.
\end{abstract}

KEYWORDS: Holocene, Last Glacial Maximum, MIS 3, paleosols, relative sea level.

\section{INTRODUCTION}

In recent years, paleopedology has shifted from a largely qualitative discipline to an increasingly quantitative endeavor (Sheldon and Tabor 2009). A good example is the study of paleosols in coastal sedimentary sequences. Coastal paleosols form during protracted sea level lowstands associated with glacial stadials, such as during the last glacial maximum (LGM). Paleosols often form relatively thick, solitary units that can be used as basin-wide stratigraphic markers of sea level lowering. Examples include Late Quaternary paleosols from the Changjiang Delta (Chen et al. 1996, 2008; Li and Wang 1998); Yellow Sea, western coast of Korea (Lim and Park 2003; Choi 2005); Mississippi River Delta (Fisk 1944; Aslin and Autin 1998; Autin and Aslan 2001), and Po River coastal plain on the Adriatic Sea (Amorosi et al. 2016; Bruno et al. 2017; Morelli et al. 2017). Paleosols provide information about changes in sediment deposition, subsidence, erosion and pedogenesis (Kraus 1999). In a deltaic setting, the thickness and extent of weathering of a particular paleosol reflects the lateral variability associated with basin topography, and site-specific sedimentation. Coastal paleosols can serve as key stratigraphic markers in reconstructing the glacial-deglacial sequence stratigraphy of a deltaic system, and their relationship to sea level.

Here, we extend the work of Shang et al. (2018), who studied the sedimentological history and paleoclimate of the Oujiang Delta since MIS3, based on the lithological, palynological, and microfossil characteristics of cored sediments. In this paper we focus on two paleosols from the Oujiang Delta. These coastal paleosols formed when sea level dropped, and place constraints on former sea level. We verify that these deposits are paleosols based on lithological characteristics, clay mineralogy, major element chemistry, and $\mathrm{Rb} / \mathrm{Sr}$ content. Radiocarbon $\left({ }^{14} \mathrm{C}\right)$ dates from charcoal and plant material contained in the paleosols show that one paleosol formed during a period of changing sea level in the Early Holocene, and the other paleosol formed during a time of sea level lowering, near the end of Marine Isotope Stage 3 (MIS 3). Our goal in this article is to is understand the relationship between the paleosols and eustatic sea level change.

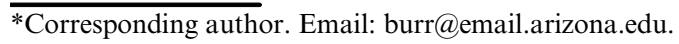




\section{The Oujiang Delta}

The Oujiang Delta was selected for study because it is a relatively straightforward system, fed by sediments carried by a single river. It is the second largest river in Zhejiang Province and drains an area of about $18,000 \mathrm{~km}^{2}$ from low-lying coastal mountains to the south and west into the East China Sea (Figure 1). The mean annual water discharge of the Oujiang River is $1.67 \times 10^{10} \mathrm{~m}^{3}$ and the mean annual sediment discharge is $2.22 \times 10^{6}$ tons. The river originates at Baishanzu Mountain (peak elevation of $1857 \mathrm{~m}$ ) in Southwest Zhejiang Province, and winds $388 \mathrm{~km}$ through low mountainous terrain before debouching into Yueqing Bay, east of Wenzhou (Figure 1). The bay follows the coast towards the northeast, where a number of rocky islands effectively separate it from the open ocean.

The Oujiang drainage basin experiences a subtropical monsoon climate, and is subject to typhoons in summer. The annual precipitation in the region varies from 1100 to $2200 \mathrm{~mm}$. Most of the rainfall is concentrated in summer (April to September), and summertime river runoff

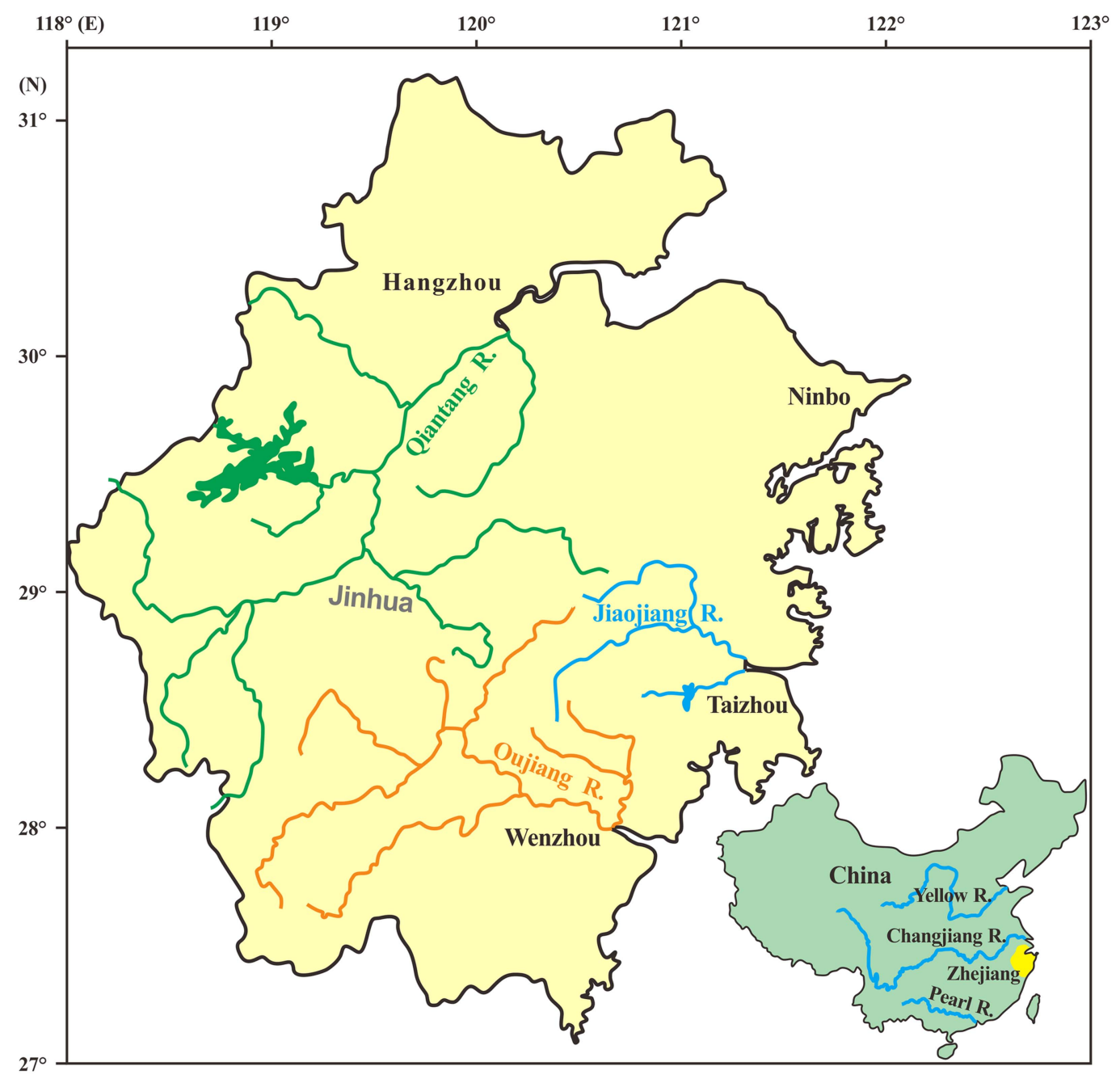

Figure 1 Map of the Oujiang River in Zhejiang Province, China. 
accounts for $78 \%$ of the annual total (Xie et al. 1994; Zhang et al. 2012). Heavy rainfall induced by typhoons can produce severe flood events in the region, with hugely disproportionate flooding, as compared with typhoon-induced flooding on large rivers, such as the Changjiang River. This is because even a small typhoon $200 \mathrm{~km}$ across $\left(\sim 30,000 \mathrm{~km}^{2}\right)$ can cover the entire Oujiang River watershed $\left(18,000 \mathrm{~km}^{2}\right)$ at one time, while the same storm can only affect less than two percent of the much larger, Changjiang River watershed $\left(1,808,500 \mathrm{~km}^{2}\right)$. These kinds of intense flooding events are analogous to those observed for small mountainous rivers in Taiwan (Liu et al. 2013), albeit with much milder stream gradients for the Oujiang River.

The mouth of the Oujiang forms a macro-tidal setting with mean and maximum tidal ranges of 4-5 $\mathrm{m}$ and 7.15 m, respectively (Li et al. 1994; Xie et al. 1994). Waves are generally low with a multi-year mean wave height of less than $0.5 \mathrm{~m}$, but a maximum wave height of over $2.4 \mathrm{~m}$ can occur when typhoons make landfall. On average, four typhoons impact the coast in this region every year (Xie et al. 1994). The present day delta and chenier plain formed following the midHolocene maximum transgression with an extreme landward boundary near Qingtian (Zhang 1990; Zhu 1993). The south flank of the delta features four shore-parallel chenier ridges (Figure 2), including (in a seaward direction): (1) the Siqian, (2) Ningcun, (3) Wuxi, and (4) Jiangding ridges (Zhu 1993). The total thickness of the Holocene strata in the study area is about 30-50 $\mathrm{m}$ (Wang et al. 1982; Yang and Chen 1982).

\section{METHODS}

\section{Core Logging and Grain-Size Analysis}

Four 11-cm-diameter cores were drilled from the Wenrui chenier plain on the south flank of the modern-day Oujiang River in June 2009 (Figure 2). These are referred to as YQ0901, YQ0902, YQ0903, and YQ0904. The elevations of the coring sites were surveyed by a trigonometric leveling method, referring to regional survey datum points. The core depth was determined directly from the length of drilling rods used for core retrieval. The location, elevation, core length and percent recovery of each core is given in Table 1. The cores were split lengthwise in

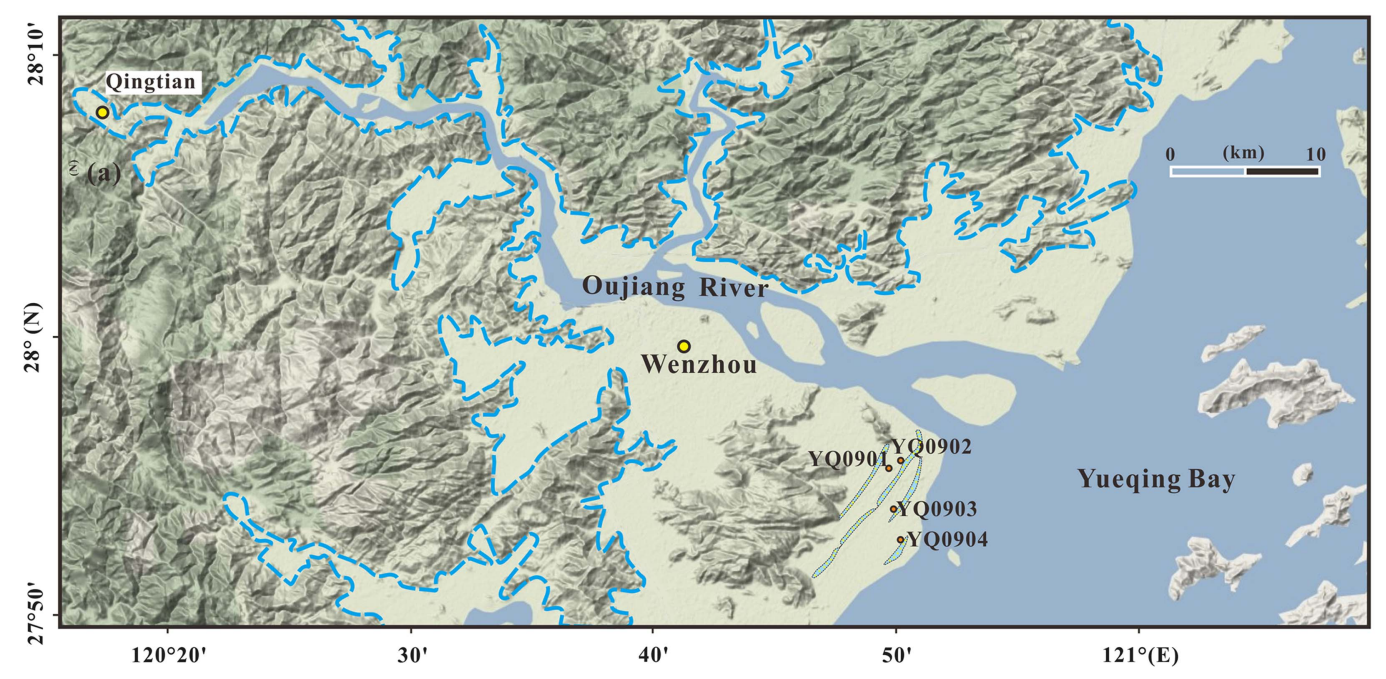

Figure 2 Drill sites (YQ0901-YQ0904) from the Oujiang Delta. Individual chenier ridges, shown in aquamarine, are Siqian ridge at the foothills, Ningcun and Wuxi ridges at the middle, and Jiangding ridge near the present coastline. 
Table 1 Borehole details from the four cores collected from the Wenrui chenier plain.

\begin{tabular}{llllll}
\hline $\begin{array}{l}\text { Core } \\
\text { ID }\end{array}$ & Latitude & Longitude & Elevation $(\mathrm{m})$ & Length $(\mathrm{m})$ & Recovery \\
\hline YQ0901 & $27^{\circ} 55^{\prime} 20^{\prime \prime} \mathrm{N}$ & $120^{\circ} 50^{\prime} 17^{\prime \prime} \mathrm{E}$ & 3.13 & 35.6 & $100 \%$ \\
YQ0902 & $27^{\circ} 55^{\prime} 27^{\prime \prime} \mathrm{N}$ & $120^{\circ} 50^{\prime} 35^{\prime \prime} \mathrm{E}$ & 3.15 & 41.9 & $\sim 95 \%$ \\
YQ0903 & $27^{\circ} 53^{\prime} 33^{\prime \prime} \mathrm{N}$ & $120^{\circ} 50^{\prime} 27^{\prime \prime} \mathrm{E}$ & 2.55 & 46.0 & $100 \%$ \\
YQ0904 & $27^{\circ} 53^{\prime} 47^{\prime \prime} \mathrm{N}$ & $120^{\circ} 51^{\prime} 9^{\prime \prime} \mathrm{E}$ & 3.11 & 36.1 & $100 \%$ \\
\hline
\end{tabular}

the laboratory, and the working surfaces of the core halves were cleaned with stainless steel knives to reveal sedimentary structures. These were photographed, described, and analyzed with a nondestructive X-ray fluorescence (XRF) core scanner before subsampling. The core descriptions include sediment color, lithology, grain-size variation, sedimentary structures, macrofossil and wood content. Subsamples were taken every two centimeters, sealed in plastic bags, and refrigerated at $4^{\circ} \mathrm{C}$, while awaiting further analyses. Large pieces of wood, charcoal, plants and shell, observable to the naked eye, were collected for accelerator mass spectrometry (AMS) ${ }^{14} \mathrm{C}$ dating.

Sediment samples were selected at $\sim 20$-cm intervals for grain-size analysis using a laser diffraction particle size analyzer (Coulter LS230) at the State Key Laboratory of Marine Geology, Tongji University. Samples were pretreated sequentially with $10 \% \mathrm{H}_{2} \mathrm{O}_{2}$ and $1 \mathrm{~N} \mathrm{HCl}$ to remove organic matter and carbonates (Fan et al. 2015). Mean grain size and the percentage of clay $(\varphi>8)$, silt $(4-8 \varphi)$, and sand $(\varphi<4)$ components were determined.

\section{XRF Analysis}

XRF spectra were measured for all of the cores in this study to extract elemental concentration data along the length of the sediment cores (Croudace et al. 2006; Richter et al. 2006). Our cores were analyzed using an Avaatech XRF Core Scanner at the State Key Laboratory of Marine Geology in Shanghai. Measurements were performed every $1 \mathrm{~cm}$ along core, with a counting time of $30 \mathrm{sec}$ and with $10 \mathrm{kV}, 30 \mathrm{kV}$, and $50 \mathrm{kV}$ acceleration voltages. The acquired XRF spectra were processed with the KEVEX software Toolbox to determine elemental abundances, including: $\mathrm{Na}, \mathrm{Al}, \mathrm{Si}, \mathrm{Ca}, \mathrm{Ti}, \mathrm{Mn}, \mathrm{Fe}, \mathrm{Rb}$, and $\mathrm{Sr}$.

In this study, we normalized the major element data to $\mathrm{Ti}$, due to its terrigenous origin, conservative nature during transport, and the XRF's analytical facility for Ti measurements (Murray and Leinen 1996; Hennekam and de Lange 2012). The relative element content, and single element counts normalized to total counts at $10 \mathrm{kV}$ acceleration voltage, were used to reduce system error (Revel et al. 2010; Wu et al. 2012).

\section{ICP-AES Analysis}

A total of 69 subsamples were collected from core YQ0904 at 50-cm intervals. The concentrations of major elements were determined with ICP-AES (IRIS Advantage) in the State Key Laboratory of Marine Geology, Tongji University (Shanghai). All of the bulk sediment samples were combusted in a muffle furnace at $600^{\circ} \mathrm{C}$ for $2 \mathrm{hr}$ before acid digestion to determine loss on ignition. The samples were then dissolved in a mixture of $\mathrm{HNO}_{3}$ and $\mathrm{HF}$ on a hot plate. Replicate analyses $(\mathrm{N}=20)$ of GSR-5, GSR-6, and GSD-9 standards during the study gave an accuracy of $4 \%$ for major and trace elements. 


\section{Clay Mineral Analysis}

Clay mineral assemblages were analyzed by X-ray powder diffraction (XRD) at the State Key Laboratory of Marine Geology, Tongji University (Shanghai). Sample pretreatment and oriented mounts followed the methodology of Liu et al. (2003). Clay minerals were identified based on the position of (001) basal reflections. Four major clay mineral contents, including smectite (including mixed-layers) $(15-17 \AA)$, illite (10 $)$ ), and kaolinite/chlorite $(7 \AA)$, were calculated according to semi-quantitative estimates of peak areas of the basal reflections using MacDiff software (Petschick et al. 1996). No weighting factors were used when calculating the relative weight percentages of each clay mineral. The precision of replicate analyses of selected samples was $\pm 2 \%(2 \sigma)$, and the accuracy of semi-quantitative evaluation of each clay mineral was $\sim 5 \%$.

\section{Radiocarbon Dating}

A detailed ${ }^{14} \mathrm{C}$ chronology for core YQ0902 has been reported by Shang et al. (2018) and a complete set of ${ }^{14} \mathrm{C}$ measurements for all four cores are reported by Shang (2018). AMS ${ }^{14} \mathrm{C}$ measurements were obtained from Beta Analytic and the University of Arizona. The sample results reported here were from plant remains and charcoals. These were cleaned using a standard acid-alkali-acid pretreatment (Burr and Jull 2010). All of the paleosol layers and overlying sediments were dated directly. ${ }^{14} \mathrm{C}$ ages were also obtained from the underlying sediments in two of the cores. ${ }^{14} \mathrm{C}$ dates reported in Shang et al. (2018) were recalibrated here using the Calib Rev 7.04 program (http://calib.qub.ac.uk/calib/calib.html) with the IntCal13 dataset (Reimer et al. 2013).

\section{RESULTS}

\section{Two Paleosols from the Wenrui Plains}

Each sediment core contained one paleosol. These were recognized by characteristic lithologic features, including: stiff clays, abundant yellow-brown and gray mottles, brown oxidized layers, and calcareous concretions - sometimes with brown oxidized cores. The ${ }^{14} \mathrm{C}$ results show unambiguously that the two paleosols formed at different times (Table 2). Figure 3 summarizes the dating results. Cores YQ0901 and YQ0902 penetrated a paleosol dating to MIS 3, with a marked unconformity between the paleosol and Holocene sediments. Cores YQ0903 and YQ0904 penetrated a paleosol dating to the Early Holocene with no obvious age unconformity. Six of the dates were not in chronological order, which is typical of deltaic sedimentation where the opportunity for sediment reworking is high (Stanley and Chen 2000). Two of the outliers were reworked charcoals found in an erosional horizon at the unconformity just above the MIS 3 paleosol. Aside from these two outliers, all of the dates within the MIS 3 paleosol and underlying units date to MIS 3, and all of the dates from cores YQ0903 and YQ0904 date to the Holocene (Figure 3).

\section{Sediment Features of the YQ0902 Core}

The sediments from core YQ0902 are shown in Figure 4. Depositional units (DU) are numbered from the base of the core upward. The depositional environment of the unit that underlies the MIS 3 paleosol (DU3) is lagoonal. This unit is gradational with the overlying paleosol. A conspicuous erosional surface defines the upper boundary of DU4, and this is overlain unconformably by Holocene sediments (DU5).

\section{DU3 (Lagoon): $32.16 \sim 30.26 \mathrm{~m}$}

DU3 consists of grey and dark grey massive mud with sandy streaks and mottles. Small plant fragments occur sporadically within the core, sometimes concentrated in laminae. The unit is 
Table $2{ }^{4} \mathrm{C}$ dates from each paleosol unit, and adjacent units. The paleosol contained in cores YQ0901 and YQ0902 dates to MIS 3, and the paleosol contained in cores YQ0903 and YQ0904 dates to the Early Holocene.

\begin{tabular}{|c|c|c|c|c|}
\hline Core ID & $\begin{array}{l}\text { AMS } \\
\text { lab number }\end{array}$ & Sample type / depth $(\mathrm{m})^{\mathrm{a}}$ & $\begin{array}{l}{ }^{14} \mathrm{C} \text { age } \mathrm{BP} \\
\pm 1 \sigma\end{array}$ & $\begin{array}{l}2 \sigma \text { calibrated } \\
\text { age range }^{b}\end{array}$ \\
\hline \multirow[t]{6}{*}{ YQ0901 } & AA99674 & Charcoal / 21.32 & $7180 \pm 160$ & $7695-8325$ cal BP \\
\hline & AA99675 & Charcoal / 24.81 & $7972 \pm 66$ & 8635-9007 cal BP \\
\hline & AA99676 & Charcoal / 26.42 & $9210 \pm 110$ & $10,200-10,670$ cal BP \\
\hline & AA99677 & Charcoal / 30.77 & $30,400 \pm 1,200$ & $31,534-36,809$ cal BP \\
\hline & AA99678 & Charcoal / 32.58 & $>49,900$ & \\
\hline & AA99679 & Charcoal / 34.61 & $>49,900$ & \\
\hline \multirow[t]{10}{*}{ YQ0902 } & AA98380 & Charcoal / 20.32 & $5460 \pm 43$ & 6183-6390 cal BP \\
\hline & Beta 297719 & Plant frag. / 22.22 & $6340 \pm 40$ & 7169-7413 cal BP \\
\hline & Beta 297720 & Charcoal / 24.66 & $15,800 \pm 70$ & $18,875-19,252$ cal BP \\
\hline & Beta 297721 & Plant frag. / 25.88 & $7880 \pm 40$ & 8584-8993 cal BP \\
\hline & AA98381 & Charcoal / 28.35 & $>49,900$ & $36,813-37,715$ cal BP \\
\hline & Beta 297722 & Charcoal / 28.75 & $>43,500$ & $31,451-32,585$ cal BP \\
\hline & Beta 297723 & Plant frag. / 29.62 & $33,590 \pm 340$ & $42,056-43,936$ cal BP \\
\hline & Beta 297724 & Plant frag. / 30.45 & $>43,500$ & \\
\hline & Beta 297725 & Plant frag. / 34.50 & $28,140 \pm 170$ & \\
\hline & Beta 297726 & Charcoal / 37.64 & $39,030 \pm 610$ & \\
\hline \multirow[t]{3}{*}{ YQ0903 } & AA99687 & Charcoal / 34.13 & $8275 \pm 54$ & 9091-9434 cal BP \\
\hline & AA99689 & Charcoal / 41.63 & $9312 \pm 57$ & $10,671-10,927$ cal BP \\
\hline & AA99690 & Charcoal / 43.69 & $9510 \pm 160$ & $10,303-11,225$ cal BP \\
\hline \multirow[t]{3}{*}{ YQ0904 } & AA98392 & Charcoal / 27.69 & $7993 \pm 50$ & 8652-9008 cal BP \\
\hline & AA98393 & Charcoal / 31.49 & $6120 \pm 100$ & 6752-7251 cal BP \\
\hline & AA98394 & Charcoal / 33.15 & $8720 \pm 330$ & $8988-10,677$ cal BP \\
\hline
\end{tabular}

${ }^{\mathrm{a}}$ Depths are meters from the top of the core.

${ }^{\mathrm{b}}$ Finite ${ }^{14} \mathrm{C}$ dates were calibrated with CALIB 7.04.

${ }^{\mathrm{c} 14} \mathrm{C}$ data for core YQ0902 are from Shang et al. (2018).

nearly free of shell debris. The mean grain size of DU3 is $6.8 \sim 7.3 \varphi$ and the sand content is less than $6 \%$. DU3 is rich in benthic foraminifera, with larger individual tests than neighboring units, but contains no marine ostracoda. This unit dates to the early-mid MIS 3 period (Shang et al. 2018).

\section{DU4 (MIS 3 Paleosol): $30.26 \sim 29.15 \mathrm{~m}$}

DU4 is characterized by consolidated soils with mottled colors varying from brownish-yellow and grayish-yellow to light blue (Figure 4). The stiff texture and color of DU4 make it easy to differentiate from the depositional units above and below. Calcareous concretions are widely scattered within this unit, but plant and shell fragments are scarce. The mean grain size is $6.8 \sim 7.4 \varphi$ and the sand content is relatively low. The foraminiferal abundance is relatively high near the lower boundary but decreases rapidly upward in the core.

\section{DU5 (Intertidal Flat): 29.15 25.07 m}

DU5 consists of grey sandy mud and yellow-yellowish brown muddy sand with obvious bioturbation. The erosional surface at the base of the unit is overlain by thick alternating layers of coarse sand and mud (Figure 4). A fining-upward sequence is observed, and the color of the sediments change from yellowish brown near the bottom of the unit, to gray near the 


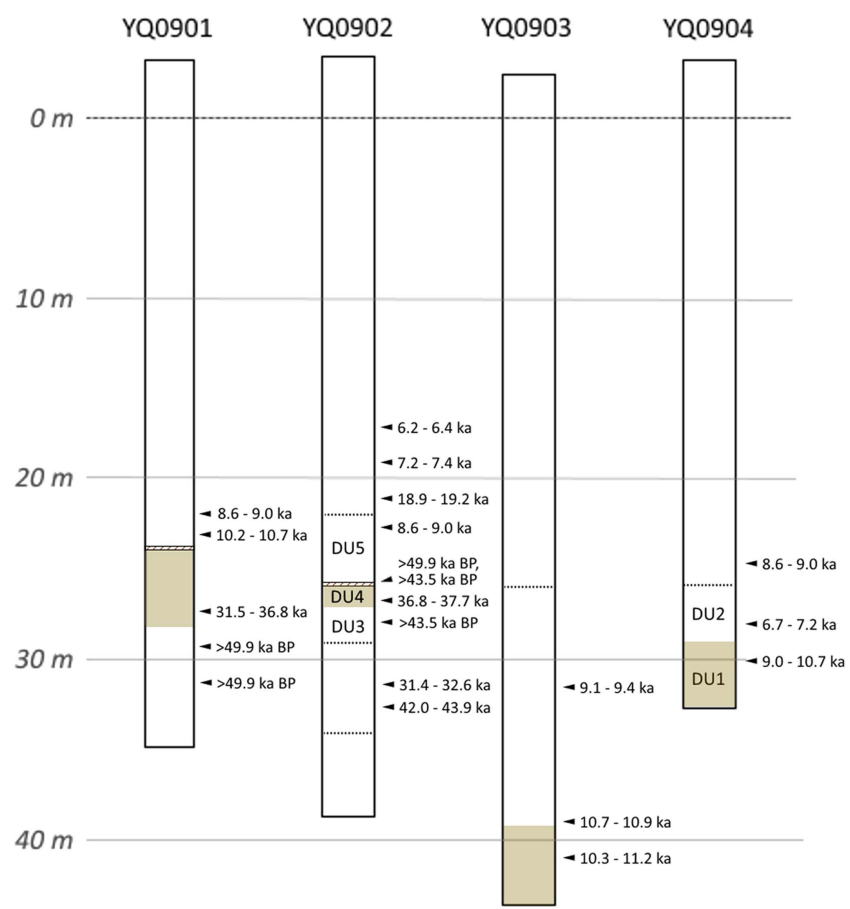

Figure $3{ }^{14} \mathrm{C}$ ages from the four cores. Depositional units (DU) are shown for the paleosols and adjacent units (see text). The MIS 3 paleosol (DU4) was found in cores YQ0901 and YQ0902, and the Early Holocene paleosol (DU1) was found in cores YQ0903 and YQ0904. Holocene sediments lie unconformably above the MIS 3 paleosol.
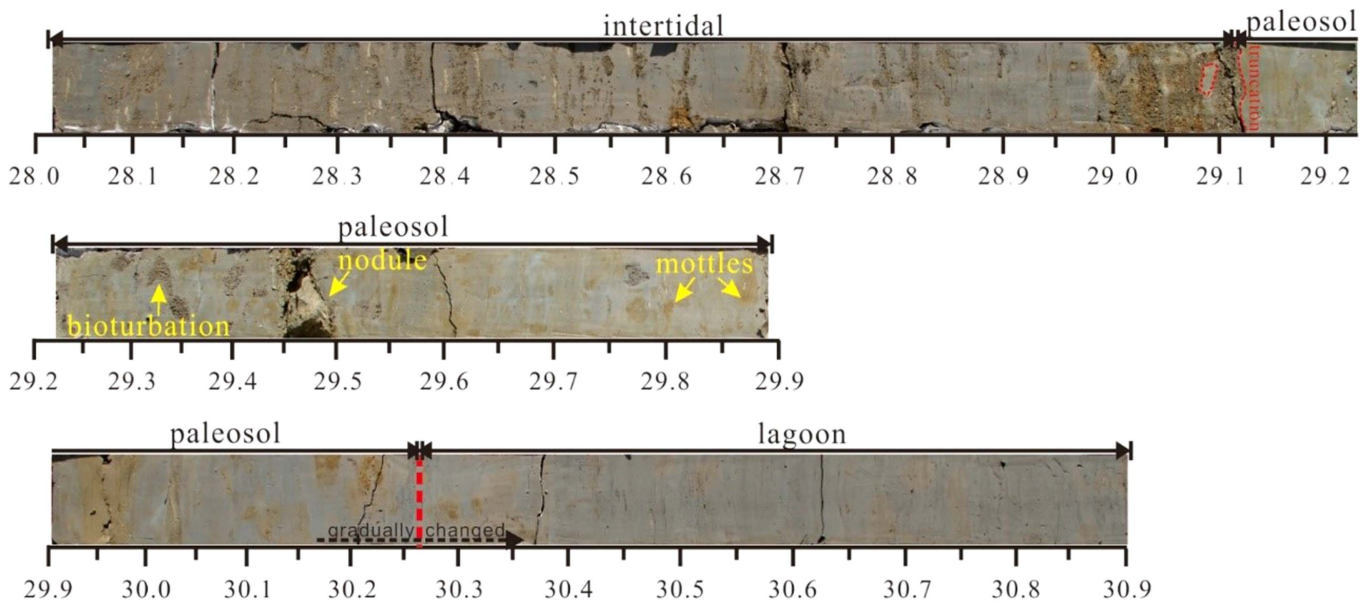

Figure 4 Core YQ0902 sediments, containing the MIS 3 paleosol.

top (Figure 4). The mean grain size ranges between 4.6 7.2 $\varphi$, and the sand content varies markedly, from $0.1 \%$ to $49.6 \%$. Plant and shell fragments are widely distributed throughout. Foraminifers, marine ostracoda and Sinocytheridea impressa are observed and gradually increase upward in the unit. 


\section{Sediment Features of the YQ0904 Core}

Core YQ0904 is shown in Figure 5 as representative of the lithology of the Early Holocene paleosol and overlying sediments. In contrast to the MIS 3 paleosol, the contact with the overlying strata is gradational, with no obvious unconformity.

\section{DU1 (Paleosol): 32.09 36.11 m}

DU1 is brownish-yellow and grayish-yellow unit that contains a 30 -cm-thick section of dark grey sediments with shell fragments, centered around $34.65 \mathrm{~m}$ depth (Figure 5). We refer to sediments above this dark grey layer as the upper paleosol and those below as the lower paleosol. Compared to the overlying unit, the DU1 paleosol contains relatively stiff clays, but not so well-indurated as the MIS 3 paleosol. Minor wood debris and shells are scattered throughout the unit, and some concretions can be seen. One concretion, found at $32.45 \mathrm{~m}$ depth, is $6 \mathrm{~cm}$ long and $3 \mathrm{~cm}$ in diameter. The lower paleosol features well-developed mottles, with brown cores and yellowish rims. The upper paleosol exhibits weaker mottling.

\section{DU2 (Marsh): 29.10 32.09 m}

DU2 consists of massive grey silty clay with a few silty lamina. The lower part of this unit contains a large concretion and persistent mottles that are gradational with the underlying paleosol. A small amount of wood debris is scattered throughout the unit, along with some shell fragments. The gradual contact between DU2 and the underlying paleosol suggests an environment of near-continuous sedimentation.

\section{Element Compositions of YQ0902 and YQ0904}

Element ratios obtained by XRF core scanning and major element compositions from ICP-AES results, expressed as oxide percentages, are presented here for the paleosol layers in
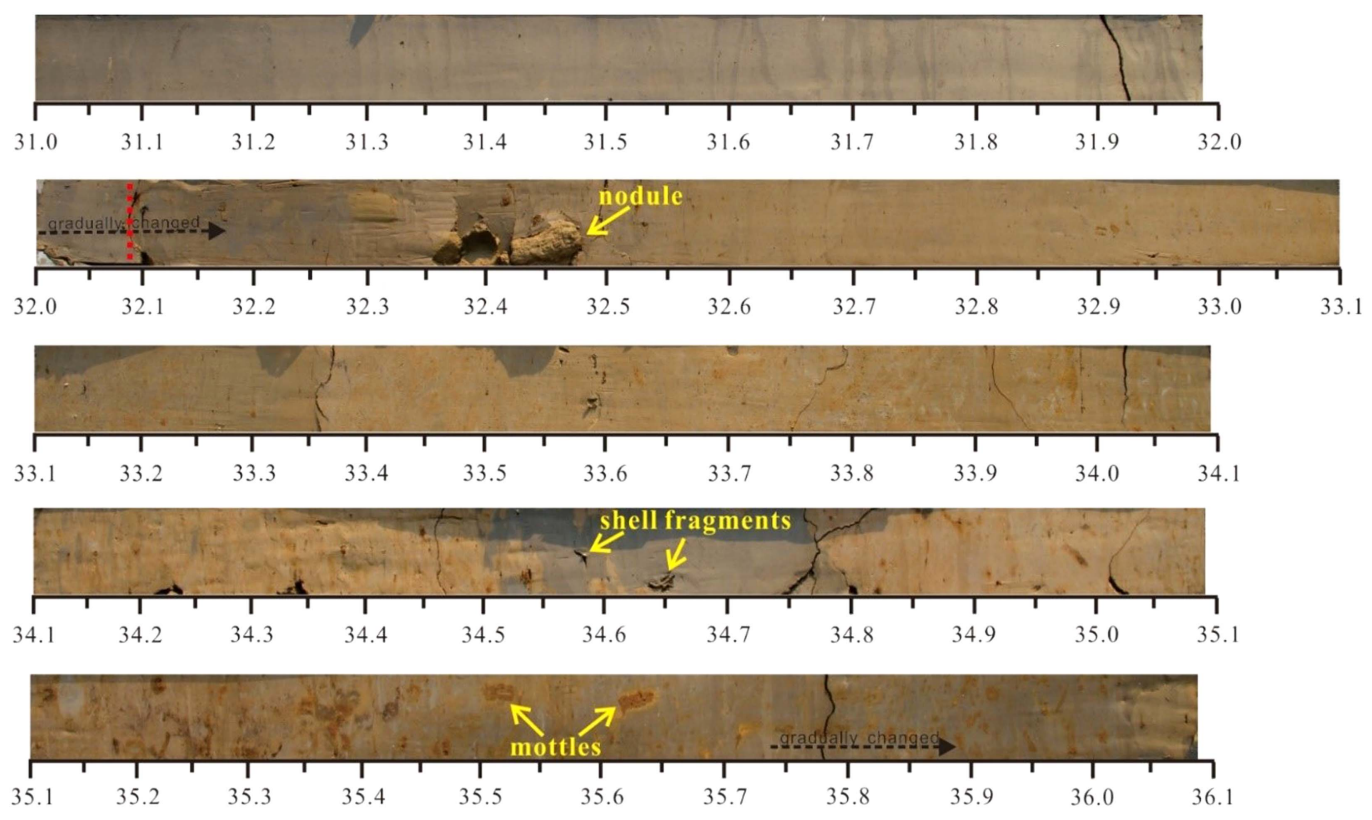

Figure 5 Core YQ0904 sediments, containing the Early Holocene paleosol. 
YQ0902 and YQ0904 (Table 3). Averaged elemental ratios, including: Al/Ti, Si/Ti, K/Ti, Ca/ $\mathrm{Ti}, \mathrm{Mn} / \mathrm{Ti}, \mathrm{Fe} / \mathrm{Ti}$, and Rb/Sr in DU3, DU4 and DU5, from core YQ0902, and DU1 and DU2, from core YQ0904, are shown in Figures 6 and 7, respectively.

\section{XRF Results from the YQ0902 and YQ0904 Cores}

Major elemental ratios in the basal unit of YQ0902 (DU3) are relatively uniform (Figure 6). By comparison, the overlying MIS 3 paleosol (DU4) exhibits significant down core variability, with $\mathrm{Ca} / \mathrm{Ti}, \mathrm{Mn} / \mathrm{Ti}, \mathrm{Fe} / \mathrm{Ti}$, and $\mathrm{K} / \mathrm{Ti}$ concentrated in discrete layers (Figure 6). This variability stems from the presence of nodules and oxidized layers, seen in the core lithology (Figure 4). The Holocene sediments of the overlying layer, DU5, mark a return to uniform major element chemistry, with the exception of high $\mathrm{Al} / \mathrm{Si}$ variability, and a highly oxidized basal layer between 29.0 and $29.15 \mathrm{~m}$ depth, immediately above the unconformity between DU4 and DU5.

A similar pattern is seen in the Early Holocene paleosol unit (DU1), at the base of the YQ0904 core. The variance observed in $\mathrm{Ca} / \mathrm{Ti}, \mathrm{Mn} / \mathrm{Ti}$ and $\mathrm{Fe} / \mathrm{Ti}$ in DU1 is notably higher than in the overlying unit (DU2). The variability is most notable in the upper paleosol (above $34.5 \mathrm{~m}$ depth), corresponding to a distinctly oxidized layer rich in $\mathrm{Ca} / \mathrm{Ti}, \mathrm{Mn} / \mathrm{Ti}$ and $\mathrm{Fe} / \mathrm{Ti}$ at about $32.25 \mathrm{~m}$, and low $\mathrm{K} / \mathrm{Ti}$ and $\mathrm{Al} / \mathrm{Si}$ ratios throughout the upper section (Figure 7). The presence of mottles in DU1 have little influence on the major element chemistry. $\mathrm{Ca} / \mathrm{Ti}$ values show a conspicuous increase in the grey sediment layer at about $34.5 \mathrm{~m}$ depth (Figure 5).

Both of the paleosols have high $\mathrm{Rb} / \mathrm{Sr}$ values, as compared to adjacent units. In the MIS 3 paleosol in YQ0902 (DU4), Rb/Sr values are about 30\% higher than in the enclosing units: DU3 below, and DU5 above (Figure 6). In the Early Holocene paleosol from the YQ0904 core (DU1), the $\mathrm{Rb} / \mathrm{Sr}$ values are also about 30\% higher than the adjacent unit, DU2 (Figure 7).

\section{Clay Mineral Assemblage of the Early Holocene Paleosol in YQ0904}

The clay mineral assemblages from depositional unit DU1, core YQ0904, are shown in Table 4. There is a distinct change in the proportions of clay minerals at about $34.2 \mathrm{~m}$ depth

Table 3 Major element ICPMS results from paleosols DU4 and DU1 in the YQ0902 and YQ0904 cores, expressed as oxide percentages.

\begin{tabular}{lrllllllll}
\hline Depth (m) & $\mathrm{Al}_{2} \mathrm{O}_{3}$ & $\mathrm{CaO}$ & $\mathrm{Fe}_{2} \mathrm{O}_{3}$ & $\mathrm{~K}_{2} \mathrm{O}$ & $\mathrm{MgO}$ & $\mathrm{MnO}$ & $\mathrm{Na}_{2} \mathrm{O}$ & $\mathrm{P}_{2} \mathrm{O}_{5}$ & $\mathrm{TiO}_{2}$ \\
\hline Core YQ0902 (DU4) & & & & & & & & & \\
29.29 & 8.15 & 0.36 & 7.26 & 3.04 & 0.72 & 0.051 & 1.33 & 0.098 & 0.90 \\
29.55 & 11.00 & 0.65 & 5.94 & 3.33 & 1.67 & 0.102 & 1.42 & 0.109 & 0.88 \\
29.93 & 11.47 & 1.23 & 4.78 & 2.61 & 1.40 & 0.060 & 1.38 & 0.093 & 0.96 \\
30.15 & 9.12 & 1.91 & 6.70 & 2.46 & 1.31 & 0.085 & 1.41 & 0.114 & 0.95 \\
Core YQ0904 (DU1) & & & & & & & & & \\
32.19 & 9.57 & 0.55 & 7.30 & 2.54 & 0.63 & 0.173 & 1.31 & 0.114 & 1.10 \\
32.69 & 8.51 & 0.18 & 4.54 & 2.82 & 1.00 & 0.036 & 0.78 & 0.077 & 1.04 \\
33.19 & 15.29 & 0.15 & 5.80 & 3.13 & 1.07 & 0.037 & 0.91 & 0.061 & 1.00 \\
33.69 & 13.24 & 0.15 & 5.91 & 3.10 & 0.91 & 0.045 & 1.15 & 0.058 & 0.94 \\
34.19 & 9.84 & 0.44 & 6.81 & 3.25 & 0.81 & 0.183 & 1.25 & 0.113 & 0.98 \\
34.69 & 9.80 & 0.86 & 6.74 & 3.26 & 1.97 & 0.219 & 1.56 & 0.135 & 0.86 \\
35.19 & 13.40 & 0.58 & 6.62 & 2.77 & 1.18 & 0.185 & 1.65 & 0.120 & 0.90 \\
35.69 & 10.64 & 0.56 & 7.76 & 3.29 & 1.49 & 0.066 & 1.54 & 0.157 & 0.95 \\
\hline
\end{tabular}




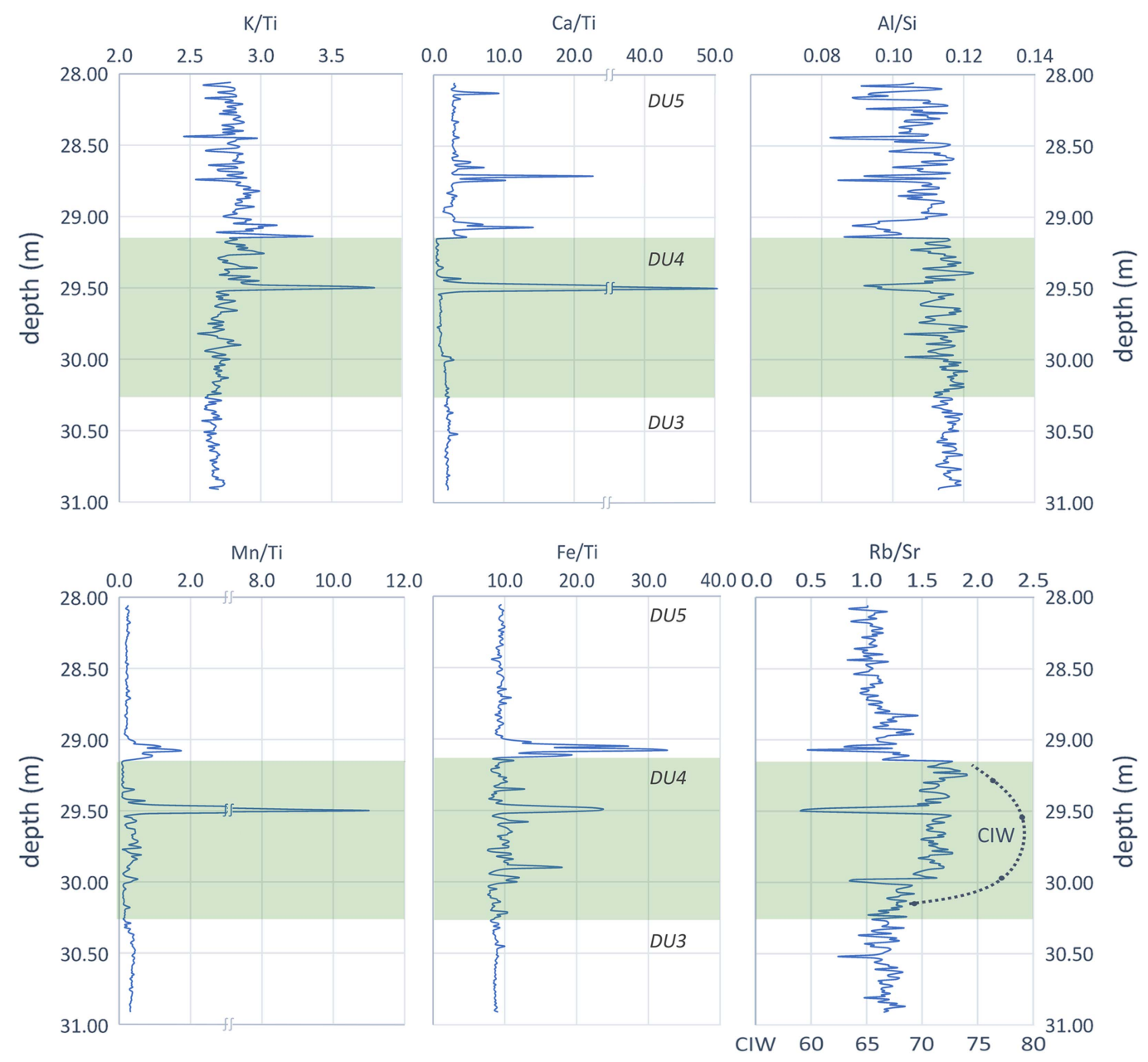

Figure 6 XRF elemental abundance ratios (K/Ti, Ca/Ti, Mn/Ti, Fe/Ti, Al/Si, Rb/Sr) and Chemical Index of Weathering (CIW) profiles for core YQ0902, with depositional units DU3, DU4 and DU5.

( $2 \mathrm{~m}$ from the top of the paleosol), that corresponds to a decrease in $\mathrm{Rb} / \mathrm{Sr}$ values (Figure 7). Illite is the dominant clay mineral in the top $2 \mathrm{~m}$ of the paleosol, with some smectite in the uppermost strata. The proportion of smectite diminishes rapidly down core, to $1 \%$, and then climbs sharply again at $34.2 \mathrm{~m}$ depth. It reaches $49 \%$ at the base of the core and the rise in smectite in the lower paleosol is accompanied by a proportional drop in illite, chlorite and kaolinite.

\section{DISCUSSION}

The paleosols from this study can be classified as calcic gleysols according to the taxonomic scheme of Mack et al. (1993). These are typical of environments with a high and fluctuating water table. Varying degrees of redox reactions and nodule growth are common among calcic gleysols, giving rise to yellow to grey coloration, a mottled texture, and brown, oxidized zones. This lithological interpretation is also consistent with the $\mathrm{K} / \mathrm{Ti}, \mathrm{Ca} / \mathrm{Ti}, \mathrm{Mn} / \mathrm{Ti}$, and $\mathrm{Fe} / \mathrm{Ti}$ variations that we observe at discrete levels within both paleosols, where nodules have formed. 

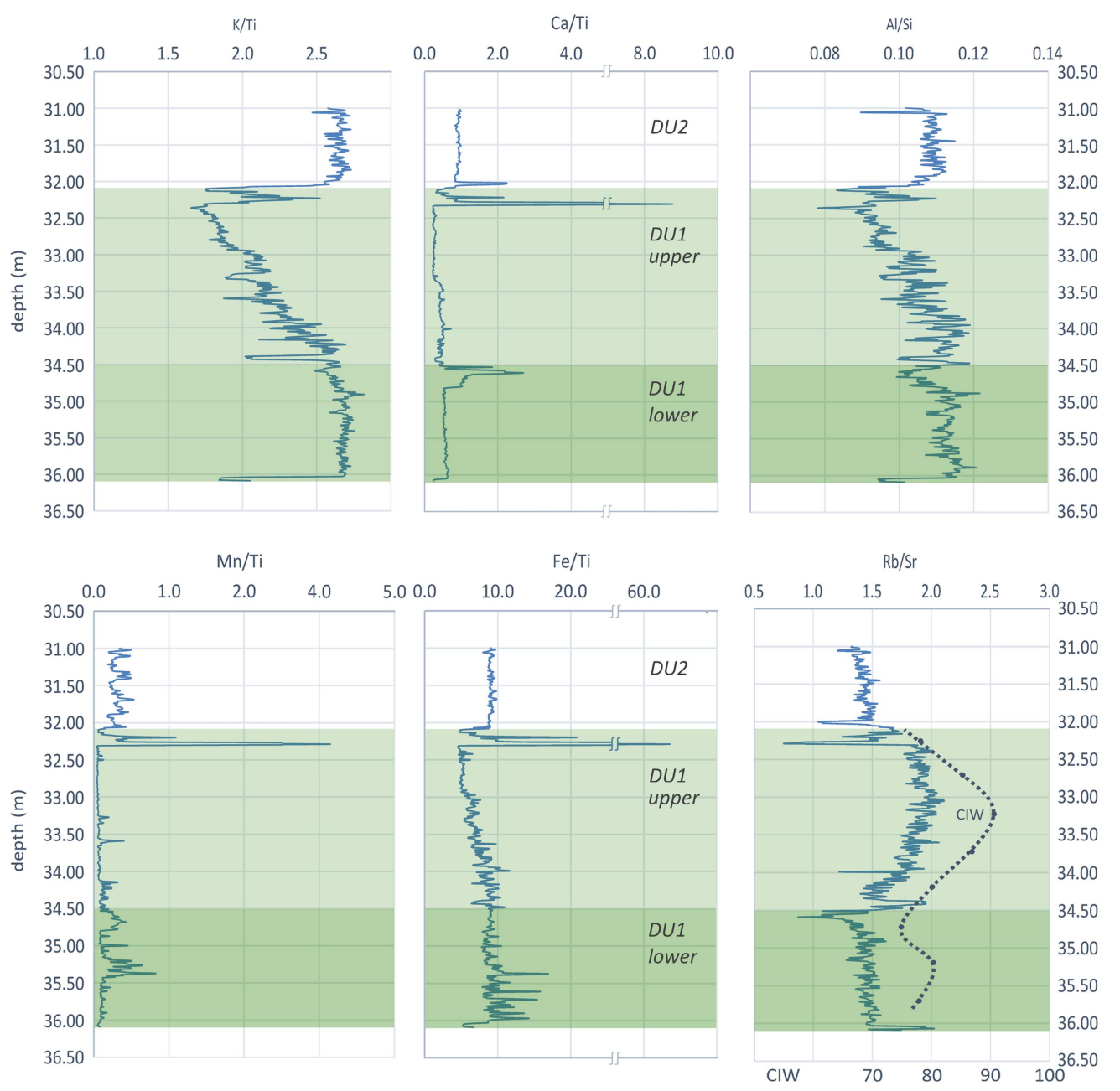

Figure 7 XRF elemental abundance ratios (K/Ti, Ca/Ti, Mn/Ti, Fe/Ti, Al/Si, Rb/Sr) and Chemical Index of Weathering (CIW) profiles for core YQ0904, with depositional units DU1 and DU2.

Table 4 Clay minerals proportions in DU1 (Early Holocene paleosol, core YQ0904).

\begin{tabular}{lllll}
\hline Depth $(\mathrm{m})$ & Smectite $(\%)$ & Illite $(\%)$ & Kaolinite $(\%)$ & Chlorite $(\%)$ \\
\hline 32.19 & 19 & 46 & 10 & 25 \\
32.69 & 1 & 62 & 12 & 25 \\
33.19 & 1 & 65 & 10 & 24 \\
33.69 & 4 & 62 & 10 & 24 \\
34.19 & 26 & 53 & 8 & 13 \\
34.69 & 41 & 34 & 7 & 48 \\
35.19 & 43 & 45 & 7 & 6 \\
35.69 & 49 & 39 & 7 & \\
\hline
\end{tabular}


For example, we observe a nodule at $29.5 \mathrm{~m}$ depth in the MIS 3 paleosol (Figure 4), and a similar nodule at $32.4 \mathrm{~m}$ depth, in the Early Holocene paleosol (Figure 5). Both of these depths correspond to sharp peaks in $\mathrm{K} / \mathrm{Ti}, \mathrm{Ca} / \mathrm{Ti}, \mathrm{Mn} / \mathrm{Ti}$ and $\mathrm{Fe} / \mathrm{Ti}$ (Figures 6 and 7).

The clay mineral data also point to pedogenesis. A distinct change in clay mineral assemblage is observed between 33.7 and $34.2 \mathrm{~m}$ depth in the YQ0904 core, at the divide between the upper and lower Early Holocene paleosol. Chlorite, kaolinite and illite are abundant in the upper paleosol, with very little smectite; whereas smectite becomes a primary clay mineral in the lower paleosol, along with illite. These features are consistent with a higher degree of chemical weathering in the upper paleosol.

Chemical weathering is a natural consequence of pedogenesis. In general, chemical weathering increases the relative amount of alumina in sediments, as clays form from feldspars, and calcium and sodium are removed by dissolution. This can be expressed as a chemical index of weathering (CIW, Harnois 1988):

$$
\mathrm{CIW}=\left[\mathrm{Al}_{2} \mathrm{O}_{3} /\left(\mathrm{Al}_{2} \mathrm{O}_{3}+\mathrm{CaO}+\mathrm{Na}_{2} \mathrm{O}\right)\right] \times 100
$$

Higher CIW values indicate a greater degree of chemical weathering. We used the ICPMS data in Table 3 to calculate CIW-depth profiles for both paleosols. The absolute values indicate significant chemical weathering, with a maximum within a meter of the top of each paleosol (Figures 6 and 7). The CIW curve for the Early Holocene paleosol shows two maxima, which suggests that it is a compound paleosol, with two periods of emergence. Compound paleosols are common in the Changjiang Delta, north of the study area (Chen et al. 2008).

$\mathrm{Rb} / \mathrm{Sr}$ values can also reflect the degree of chemical weathering in paleosols (Chen et al. 1999; Jin et al. 2001; Hong et al. 2013). Strontium dissolution in soils follows the same pathways as calcium, while rubidium follows potassium. Since these two elements are concentrated in different mineral phases, ensuing chemical weathering fractionates the two elements (Jin et al. 2006). This is observed in both of our paleosols, with elevated $\mathrm{Rb} / \mathrm{Sr}$ values, as compared to adjacent depositional units. The $\mathrm{Rb} / \mathrm{Sr}$ trends from both paleosols mirror those of the CIW values, with a maximum value within a meter of the top of the paleosol (Figure 6R, Figure 7R).

The lithologic features, major element chemistry, clay mineral profiles, Rb/Sr profiles, and CIW profiles from DU1 and DU4 confirm their interpretation as paleosols. Since deposition occurred underwater and pedogenesis occurred after emergence, these units can be used to bracket sea level. The ${ }^{14} \mathrm{C}$ dates allow us to place an upper limit on their depositional ages, and on the timing of pedogenesis. We can interpret this transition with reference to a eustatic sea level curve (Figure 8). The $2 \sigma$ calibrated age range for the MIS 3 paleosol in core YQ0901 is 31.5 to $36.8 \mathrm{cal} \mathrm{ka} \mathrm{BP}$, and the $2 \sigma$ range for YQ0902 is 36.8 to $37.7 \mathrm{cal} \mathrm{ka} \mathrm{BP}$, both measured on charcoal and both from about $-27 \mathrm{~m}$ depth, relative to today's sea level (Table 1). This date represents a maximum age for the paleosol, because the charcoal was incorporated into the sediments before emergence, and the upper surface of the paleosol has been eroded. Shortly before the charcoals were deposited in our two MIS 3 paleosols, between $40 \mathrm{ka} \mathrm{BP}$ and $38 \mathrm{ka}$ BP, global sea level rose by approximately $20 \mathrm{~m}$, from around $-90 \mathrm{~m}$ to $-70 \mathrm{~m}$ (Siddall et al. 2008), seemingly providing an environment for subaqueous sedimentation at our site. However, our paleosols are at a depth of about $-27 \mathrm{~m}$, above the expected sea level from measurements on 


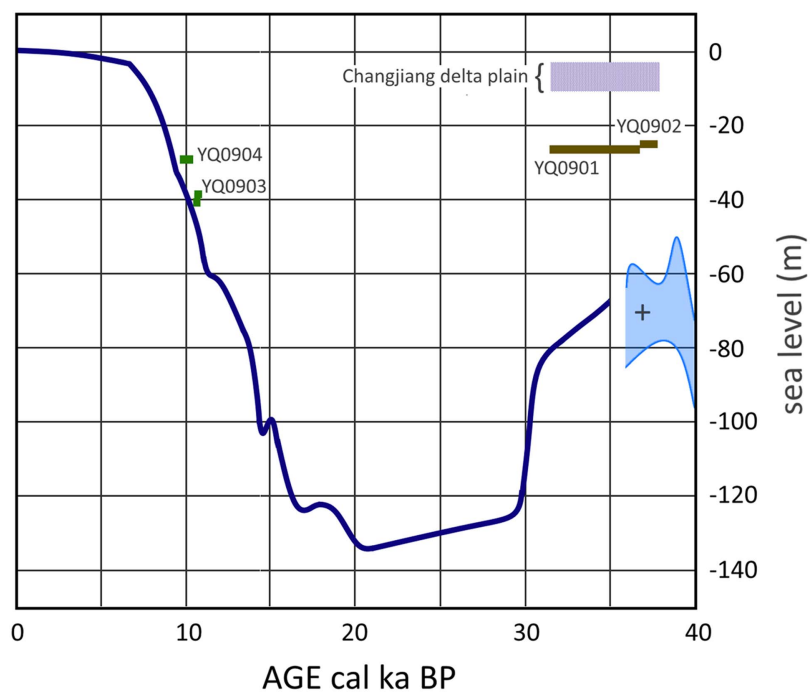

Figure 8 Age-depth relationships of the MIS 3 (YQ0901 and YQ0902) paleosols and the Early Holocene (YQ0903 and YQ0904) paleosols, compared to relative sea level for the past $40 \mathrm{ka}$. The dark blue curve is the ice-volume equivalent sea level curve of Lambeck et al. (2014). The light blue shaded region is the range of values from four different relative sea level curves summarized by Siddall et al. (2008). These include paleo sea level data from Chappell (2002), Thompson and Goldstein (2006), Arz et al. (2007), and Shackleton et al. (2000). The cross is a U/Th date and inferred relative sea level from a coral that lived near the surface in Papua New Guinea (Cutler et al. 2003). The Changjiang Delta relative sea level values for the end of MIS 3 (shown as stipled rectangle) are from Shi and $\mathrm{Yu}$ (2003), Zhao et al. (2008), and Wang et al. (2013).

corals and model values (Figure 8). This suggests a high regional sea level for the Oujiang Delta region, or possibly uplift. Regional sea level differences have been recognized for many years. Potter and Lambeck (2003) showed that differential isostatic rebound from melting glaciers can produce twenty meter differences depending on their location. Recent studies show that large regional effects can also be produced in the far field (low latitude sites responding to high latitude deglaciation) (Tamisiea and Mitrovica 2011). If the offset we observe is indeed regional, then we should expect to find other anomalous relative sea level estimates along the southeast coast of China from the same time. A number of examples have been documented from the Changjiang Delta, about $450 \mathrm{~km}$ north of the Oujiang Delta. Relative sea level estimates based on sediments from the Changjiang coastal plain suggest a relative sea level between $-5 \mathrm{~m}$ (Zhao et al. 2008; Wang et al. 2013) and $-10 \mathrm{~m}$ (Shi and $\mathrm{Yu}$ 2003) during late MIS 3. Our Oujiang Delta relative sea level value lies between these Changjiang Delta values and the eustatic sea level curve (Figure 8).

Both the Changjiang Delta and the Oujiang Delta are located adjacent to an actively subsiding continental shelf, impacted by a huge sediment load, brought by the Changjiang River. Both sites are affected because the river sediments are carried south along the coast once they reach the ocean, as part of a belt that extends for more than $1000 \mathrm{~km}$ (Liu et al. 2018). The outer Changjiang Delta has been subsiding at a rate of $1-2 \mathrm{~mm} \mathrm{a}^{-1}$ since MIS 5 (Fang 1959; Huang 1959; Yu 1959; Li et al. 2000; Wang et al. 2013), and continental shelf sediments opposite the Oujiang Delta are 
accumulating at a rate of $0.5-1 \mathrm{~mm} \mathrm{a}^{-1}$ (Xu et al. 2012). The high regional sea level we observe in both deltas could be due to local uplift caused by subsidence-induced tilting of the coastal plain sediments (Wang et al. 2013). Since the subsidence is greater offshore of the Changjiang Delta, the effect is more pronounced, as seen in the apparent late MIS 3 sea level elevations.

Unlike the MIS 3 paleosol, the relationship between sea level and the Early Holocene paleosol is straightforward (Figure 8). The Early Holocene paleosol developed nearshore, at a time of a fluctuating, stepwise, rising sea level. Fluctuating sea level led to a drop in sea level in the Early Holocene that exposed the sediments and initiated pedogenesis. The primary difference between the two paleosols is the duration of pedogenesis and the depositional environment. The duration of pedogenesis is the time that the paleosol was exposed to the atmosphere, and can be inferred from the eustatic sea level curve. According to the curve of Lambeck et al. (2014) the MIS 3 paleosol would have been many tens of meters above sea level during the LGM, and exposed for more than $20 \mathrm{ka}$. The Early Holocene paleosols must have formed near the shore, and were not exposed for longer than a thousand years. This timing explains the lithological differences between the two paleosols. In general, the MIS 3 paleosol is more mature. It is composed of stiff clays with distinct oxidized layers, and is capped by a conspicuous unconformity. The Early Holocene clays are relatively soft, with a mildly mottled texture and brown oxidized zones; and the upper surface of the Early Holocene paleosol grades continuously into the overlying sediments with no obvious unconformity.

Since these paleosols formed in response to global sea level rise, we should expect to see analogous examples elsewhere along the coast of China, and from other parts of the world. A prominent MIS 3 paleosol is widely recognized in hundreds of sediment cores from the Changjiang Delta (Chen et al. 1996; Chen and Li 1998; Li et al. 2002). As in the case of the Oujiang paleosol, the Changjiang paleosol features stiff grey clay and a mottled texture. It is overlain unconformably by Holocene sediments and forms a stratigraphic marker from which the sequence stratigraphy of post-LGM sedimentation is widely referenced (Li et al. 2002; Chen et al. 2008; Song et al. 2013). Further to the north, along the west coast of Korea, a MIS 3 paleosol dated to about 40-45 ka (optically stimulated luminescence), has been described by Chang et al. (2014). The authors note that this paleosol experienced a lengthy period of subaerial exposure. At Kyonngi Bay, on the west coast of Korea, two paleosols are observed in sediment cores: (1) a Late Pleistocene paleosol, and (2) an Early Holocene paleosol (Choi 2005). The Late Pleistocene paleosol is capped by and unconformity and the Early Holocene paleosol has a gradational boundary with the overlying sediments, just as we observe in our cores from the Wenrui plain. Another interesting analog to our Holocene paleosol is the Shandong clinoform. This is a drowned deltaic front of the Yellow River that dates to the same period as our Early Holocene paleosol, and formed in much the same manner, in response to a stepwise rising sea level (Liu et al. 2004).

\section{CONCLUSIONS}

Two paleosols of different age were found in sediments from the Oujiang Delta. The older paleosol (cores YQ0901 and YQ0902) dates to the latest MIS 3 period, with a maximum age of about $38 \mathrm{ka} \mathrm{BP}$. This paleosol was exposed far above current sea level for perhaps $20 \mathrm{ka}$ during the LGM. It features a mottled texture and stiff grey clays, with calcic concretions and brown oxidized layers rich in Mn and Fe. A similar MIS 3 paleosol has been described in numerous studies from the Changjiang Delta, where it serves as a regional stratigraphic marker. The younger Oujiang Delta paleosol (cores YQ0903 and YQ0904) dates to the Early Holocene, 9.211.2 ka BP. This paleosol formed nearshore in response to stepwise sea level increases and was 
probably not exposed for more than a thousand years. It has analogs along the west coast of Korea and is coeval with the Shandong clinoform. When plotted against a eustatic relative sea level curve, the Oujiang delta MIS 3 paleosol lies about $30 \mathrm{~m}$ above the global height. We interpret this difference to be caused by upward tilting of the Oujiang delta sediments, in response to active subsidence on the adjacent continental shelf.

\section{ACKNOWLEDGMENTS}

This research was funded by the National Natural Science Foundation of China (NSFC-41476031, 41776052), the China-ASEAN maritime cooperation fund (CAM-201501), and the National Programme on Global Change and Air-Sea Interaction (GASI-GEOGE-03). Also, Taiwan Ministry of Education Grant (NTU-107L9010). The authors would like to thank Yijing $\mathrm{Wu}$, Yangyang Wang, and Lingling Chen for their assistance in both field and laboratory work.

\section{REFERENCES}

Amorosi A, Bruno L, Cleveland DM, Morelli A, Hong W. 2016. Paleosols and associated channelbelt sand bodies from a continuously subsiding late Quaternary system (Po Basin, Italy): New insights into continental sequence stratigraphy. Geological Society of America Bulletin 129(3/4):449-63.

Arz HW, Lamy F, Ganopolski A, Nowaczyk N, Pätzold J. 2007. Dominant Northern Hemisphere climate control over millennial-scale glacial sealevel variability. Quaternary Science Reviews 26:312-21.

Aslan A, Autin WJ. 1998. Holocene flood-plain soil formation in the southern lower Mississippi Valley: Implications for interpreting alluvial paleosols. Geological Society of America Bulletin 110 (4):433-49.

Autin WJ, Aslan A. 2001. Alluvial pedogenesis in Pleistocene and Holocene Mississippi River deposits: Effects of relative sea-level change. Geological Society of America Bulletin 113(11):1456-66.

Bruno L, Amorosi A, Severi P, Costagli B. 2017. Late Quaternary aggradation rates and stratigraphic architecture of the southern Po Plain, Italy. Basin Research 29:234 48.

Burr GS, Jull AJT. 2010. Accelerator Mass Spectrometry for Radiocarbon Research. In Beauchemin D, Matthews DE, volume editors; Gross ML, Caprioli RM, series editors. The Encyclopedia of Mass Spectrometry. Volume 5, Elemental and Isotope Ratio Mass Spectrometry. p 656-669. Elsevier. 1088 p.

Chang TS, Kim JC, Yi S. 2014. Discovery of Eemian marine deposits along the Baeksu tidal shore, southwest coast of Korea. Quaternary International 349:409-18.

Chappell J. 2002. Sea level changes forced ice breakouts in the Last Glacial cycle: new results from coral terraces. Quaternary Science Reviews 21:1229-40.

Chen J, An ZS, Head J. 1999. Variation of Rb/Sr ratios in the loess-paleosol sequences of central China during the Last 130,000 years and their implications for monsoon paleoclimatology. Quaternary Research 51(3):215-9.

Chen QQ, Li CX, Li P, Liu BZ, Sun HP. 2008. Late Quaternary palaeosols in the Yangtze Delta, China, and their palaeoenvironmental implications. Geomorphology 100:465-83.

Chen QQ, Li CX. 1998. Studies on origin of the Late Pleistocene stiff clays at the Yangtze Delta. Scientia Geographica Sinica 18(1):53-7 (in Chinese).

Chen QQ, Sun HP, Li CX. 1996. Late Pleistocene paleosols and soil-forming environment at the southern flank of the Yangtze Delta. Journal of Tongji University 24(1):33-7 (in Chinese).

Choi KS. 2005. Pedogenesis of late Quaternary deposits, northern Kyonggi Bay, Korea: Implications for relative sea-level change and regional stratigraphic correlation. Palaeogeography, Palaeoclimatology, Palaeoecology 220:387-404.

Croudace IW, Rindby A, Rothwell RG. 2006. ITRAX: description and evaluation of a new multi-function X-ray core scanner. In: Rothwell $\mathrm{RG}$, editor. New Techniques in Sediment Core Analysis. London: Geological Society of London. p 51-63.

Cutler KB, Edwards RL, Taylor FW, Cheng H, Adkins J, Gallup CD, Cutler PM, Burr GS, Bloom AL. 2003. Rapid sea-level fall and deepocean temperature change since the last interglacial period. Earth and Planetary Science Letters 206:253-71.

Fan DD, Shang S, Cai GF, Tu JB. 2015. Distinction and grain-size characteristics of intertidal heterolithic deposits in the middle Qiantang Estuary (East China Sea). Geo-Marine Letters 35(3):161-74.

Fang HQ. 1959. Neotectonic movement in the middle and lower reaches of the Yangtze River. Acta Geologica Sinica 39(3):51-66 (in Chinese).

Fisk HN. 1944. Geological Investigation of the Alluvial Valley of the Lower Mississippi River. U.S. Army Corps of Engineers, Mississippi River Commission, Vicksburg, Mississippi. 78 p. 
Harnois L. 1988. The CIW index: a new chemical index of weathering. Sedimentary Geology 55:319-22.

Hennekam R, de Lange G. 2012. X-ray fluorescence core scanning of wet marine sediments: methods to improve quality and reproducibility of highresolution paleoenvironmental records. Limnology and Oceanography: Methods 10:991-1003.

Hong HL, Wang CW, Zeng KF, Gu YS, Wu YB, Yin K, Li ZH. 2013. Geochemical constraints on provenance of the mid-Pleistocene red earth sediments in subtropical China. Sedimentary Geology 290:97-108.

Huang JS. 1959. Subsidence in the Yangtze Delta. The Data of Geography 4:84-92 (in Chinese).

Jin ZD, Cao JJ, Wu JL, Wang SM. 2006. A Rb/Sr record of catchment weathering response to Holocene climate change in Inner Mongolia. Earth Surface Processes and Landforms 31(3):285-91.

Jin ZD, Wang SM, Shen J, Zhang EL, Li FC, Ji JF, Lu XW. 2001. Chemical weathering since the Little Ice Age recorded in lake sediments: a highresolution proxy of past climate. Earth Surface Processes and Landforms 26:775-82.

Kraus MJ. 1999. Paleosols in clastic sedimentary rocks: their geologic applications. Earth-Science Reviews 47:41-70.

Lambeck K, Rouby H, Purcell A, Sun YY, Sambridge M. 2014. Sea level and global ice volumes from the Last Glacial Maximum to the Holocene. Proceedings of the National Academy of Sciences 111 (43):15296-303.

Li BG, Xie QC, Xia XM, Li Y. 1994. Discussion on the sediment-dynamic processes of tidal flats along the south flank of the Oujiang River Delta. Acta Oceanologica Sinica 16(2):86-94 (in Chinese).

Li CX, Wang P, Sun HP, Zhang JQ, Fan DD, Deng B. 2002. Late Quaternary incised-valley fill of the Yangtze delta (China): its stratigraphic framework and evolution. Sedimentary Geology 152:133-58.

Li CX, Chen QQ, Zhang JQ, Yang SY, Fan DD. 2000. Stratigraphy and paleoenvironmental changes in the Yangtze Delta during the Late Quaternary. Journal of Asian Earth Sciences 18:453-69.

Li CX, Wang PX. 1998. Study on the late Quaternary estuarine stratigraphy of the Changjiang Estuary. Beijing Science Press. p 192-4 (in Chinese).

Lim DI, Park YA. 2003. Late Quaternary stratigraphy and evolution of a Korean tidal flat, Haenam Bay, Southeastern Yellow Sea, Korea. Marine Geology 193:177-94.

Liu JT, Hsu RT, Yang RJ, Wang YP, Wu H, Du XQ, Li AC, Chien SC, Lee J, Yang SY, Zhu JR, Su CC Su, Chang Y, Huh C-A. 2018. A comprehensive sediment dynamics study of a major mud belt system on the inner shelf along an energetic coast. Scientific Reports 8:4229. doi:10.1038/s41598-01822696-w. 14 p.
Liu JT, Kao S-J, Huh C-A, Hung C-C. 2013. Gravity flows associated with flood events and carbon burial: Taiwan as instructional source area. Annual Review of Marine Science 5:47-68.

Liu JP, Milliman JD, Gao S, Cheng P. 2004. Holocene development of the Yellow River's subaqueous delta, North Yellow Sea. Marine Geology 209:45-67.

Liu ZF, Trentesaux A, Clemens SC. 2003. Quaternary clay mineralogy in the northern South China Sea (ODP Site 1146) - Implications for oceanic current transport and East Asian monsoon evolution. Science in China Series D - Earth Sciences 46 (12):1223-35.

Mack GH, James WC, Monger HC. 1993. Classification of paleosols. Geological Society of America Bulletin 105:129-36.

Morelli A, Bruno L, Cleveland DM, Drexler TM, Amorosi A. 2017. Reconstructing Last Glacial Maximum and Younger Dryas paleolandscapes through subsurface paleosol stratigraphy: An example from the Po coastal plain, Italy. Geomorphology 295:790-800.

Murray W, Leinen M. 1996. Scavenged excess aluminum and its relationship to bulk titanium in biogenic sediment from the central equatorial Pacific Ocean. Geochimica et Cosmochimica Acta 60(20):3869-78.

Petschick R, Kuhn G, Gingele F. 1996. Clay mineral distribution in surface sediments of the South Atlantic: sources, transport, and relation to oceanography. Marine Geology 130(3-4):203-29.

Potter E-K, Lambeck K. 2003. Reconciliation of sealevel observations in the western North Atlantic during the last glacial cycle. Earth and Planetary Science Letters 217:171-81.

Reimer PJ, Bard E, Bayliss A, Beck JW, Blackwell PG, Ramsey CB, Buck CE, Cheng H, Edwards RL, Friedrich M, Grootes PM, Guilderson TP, Haflidason H, Hajdas I, Hatte C, Heaton TJ, Hoffmann DL, Hogg AG, Hughen KA, Kaiser KF, Kromer B, Manning SW, Niu M, Reimer RW, Richards DA, Scott EM, Southon JR, Staff RA, Turney CSM, van der Plicht J. 2013. Intcal13 and Marine13 radiocarbon age calibration curves $0-50,000$ years cal BP. Radiocarbon 55(4):1869-87.

Revel M, Ducassou E, Grousset FE, Bernasconi SM, Migeon S, Revillon S, Mascle J, Murate A, Zaragosi S, Bosch D. 2010. 100,000 Years of African monsoon variability recorded in sediments of the Nile margin. Quaternary Science Reviews 29(1112):1342-62.

Richter TO, van der Gaast S, Koster B, Vaars A, Gieles R, de Stigter HC, de Haas H, van Weering TCE. 2006. The Avaatech XRF core scanner: technical description and applications to $\mathrm{NE}$ Atlantic sediments. In: Rothwell RG, editor. New Techniques in Sediment Core Analysis. London: Geological Society of London. p 39-50.

Shackleton JJ, Hall MA, Vincent E. 2000. Phase relationships between millennial-scale events 
64,000-24,000 years ago. Paleoceanography 15 (6):565-9.

Shang S, Fan DD, Yin P, Burr G, Zhang MY, Wang Q. 2018. Late Quaternary environmental change in Oujiang delta along the northeastern Zhe-Min Uplift zone (southeast China) Palaeogeography, Palaeoclimatology, Palaeoecology 492:64-80.

Shang S. 2018. Late Quaternary paleoenvironmental and paleoclimate changes in the Wenrui Chenier Plain of southern Zhejiang Province [PhD dissertation]. Tongji University, School of Ocean and Earth Science. 125 p. (in Chinese).

Sheldon ND, Tabor NJ. 2009. Quantitative paleoenvironmental and paleoclimatic reconstruction using paleosols. Earth-Science Reviews 95:1-52.

Shi YF, Yu G. 2003. Warm humid climate and transgressions during 40-30kaBP and their potential mechanisms. Quaternary Science 23 (1):1-11 (in Chinese).

Siddall M, Rohling EJ, Thompson WG, Waelbroeck C. 2008. Marine Isotope Stage 3 sea level fluctuations: data synthesis and new outlook. Reviews of Geophysics 46: RG4003. doi:10.1029/2007RG000226. 29 p.

Song B, Li Z, Saito Y, Okuno J, Li Z, Lu AQ, Hua D, Li J, Li YX. 2013. Initiation of the Changjiang (Yangtze) delta and its response to the midHolocene sea level change. Palaeogeography, Palaeoclimatology, Palaeoecology 388:81-97.

Stanley DJ, Chen ZY. 2000. Radiocarbon dates in China's Holocene Yangtze Delta: Record of sediment storage and reworking, not timing of deposition. Journal of Coastal Research 16(4):1126-32.

Tamisiea M, Mitrovica JX. 2011. The moving boundaries of sea level change. Oceanography 24 (2):24-39.

Thompson WG, Goldstein SL. 2006. A radiometric calibration of the SPECMAP timescale. Quaternary Science Reviews 25:3207-15.

Wang PX, Min QB, Bian YH. 1982. Quaternary transgressive formations in Huangyan Plain, Wenzho. Marine Bulletin 1(3):27-36 (in Chinese).

Wang ZH, Jones BG, Chen T, Zhao BC, Zhan Q. 2013. A raised OIS3 sea level recorded in coastal sediments, southern Changjiang delta plain, China. Quaternary Research 79:424-38.

Wu XD, Zhang ZH, Xu XM, Shen J. 2012. Asian summer monsoonal variations during the Holocene revealed by Huguangyan maar lake sediment record. Palaeogeography, Palaeoclimatology, Palaeoecology 323-325:13-21.

Xie QC, Li BG, Xia XM, Li Y, Van Weering TjCE, Berger GW. 1994. Spatial and temporal variations of tidal flat in the Oujiang Estuary in China. Acta Geographica Sinica 49(6):509-16 (in Chinese).

Xu KH, Li A, Liu JP, Milliman JD, Yang ZS, Liu C-S, Kao S-J, Wan SM, Xu FJ. 2012. Provenance, structure, and formation of the mud wedge along inner continental shelf of the East China Sea: A synthesis of the Yangtze dispersal system. Marine Geology 291-294: 176-191.

Yang JW, Chen XL. 1982. Holocene sporopollen assemblages and their significance in coastal areas of southern Zhejiang. Journal of East China Normal University (Natural Science) 3:76-7.

Yu ZY. 1959. Neotectonic movement of the Yangtze Delta. Collection of works on geography, physical geography of the Yangtze Delta 2, 93-105. The Department of Geography, East China Normal University (in Chinese).

Zhang XC. 1990. Formation process of plains in Oujiang Estuary Area, Zhejiang Province. Journal of Northwest Normal University (Natural Science) 4:70-5 (in Chinese).

Zhang MY, Fan DD, Wu GX, Shang S, Chen LL. 2012. Palynological characters of Late Quaternary in the south flank of the Oujiang River Delta and their paleoclimate implications. Quaternary Sciences 32(6):1234 47 (in Chinese).

Zhao BC, Wang ZH, Chen J, Chen ZY. 2008. Marine sediment records and relative sea level change during late Pleistocene in the Changjiang delta area and adjacent continental shelf. Quaternary International 186:164-72.

Zhu YK. 1993. Formation and filling up of Oujiang River Estuary in Zhejing Province. Acta Geographica Sinica 48(3):254-61 (in Chinese). 